\title{
PENDAMPINGAN PENULISAN KARYA ILMIAH MELALUI PERKUMPULAN PENULIS SEKOLAH TINGGI AGAMA KRISTEN NEGERI (IAKN) TORAJA
}

\author{
Daniel Fajar Panuntun ${ }^{1}$, Yohanes Krismantyo Susanta ${ }^{2}$, Frans Paillin Rumbi ${ }^{3}$ \\ 1,3 Jurusan Kepemimpinan Kristen, IAKN Toraja \\ 2Jurusan Musik Gereja, IAKN Toraja \\ e-mail: niel398@gmail.com ${ }^{1}$, \\ yohanessusanta@gmail.com², fransrumbi24@gmail.com³
}

\begin{abstract}
Abstrak
Budaya menulis karya ilmiah di Indonesia memiliki tren yang positif. Pada Tahun 2018, Indonesia menempati urutan ke-2 negara di ASEAN yang memiliki jumlah publikasi terindeks scopus. Publikasi karya ilmiah ini menentukan kualitas akademisi dalam mengembangkan ilmunya. Berdasarkan tren ini IAKN Toraja perlu secara aktif untuk mengambil bagian dalam meningkatkan publikasi karya ilmiah nasional.Tujuan dari pengabdian ini adalah untuk meningkatkan publikasi karya ilmiah IAKN Toraja. Metode pengabdian dengan menggunakan pembelajaran aktif, kreatif, dan inovatif dengan prinsip kolaborasi antara dosen dan mahasiswa dalam menulis karya ilmiah. Hasil dari pengabdian ini adalah abstrak naskah penelitian yang siap diteruskan untuk menjadi artikel ilmiah. Abstrak tersebut telah diseminarkan dan diberi beberapa masukan yang sesuai. Artikel ilmiah yang sudah selesai dilakukan proses submisi ke open journal system yang tersebar di seluruh Indonesia.
\end{abstract}

Kata kunci: Karya IImiah, Penulisan, IAKN Toraja,

\begin{abstract}
Cultural write scientific articles in Indonesia have a positive trend. In 2018, Indonesia ranked the second country in ASEAN, which has some Scopus indexed publications. The publication of this scientific work determines the quality of academics in developing their knowledge. Based on this trend, IAKN Toraja needs to actively take part in increasing the publication of national scientific works. This dedication aims to increase the publication of scientific works of IAKN Toraja. The dedication method uses active, creative, and inovative learning with the principle of collaboration between lecturers and students in writing scientific papers. The results of this dedication are abstracts of research texts that are ready to be forwarded to become scientific articles. The abstrak was presented by author and given some proper advices. Scientific articles that have been completed then submitted to the open journal system throughout Indonesia
\end{abstract}

Keywords : Scientific Article, Writing, IAKN Toraja. 


\section{PENDAHULUAN}

Data global terkait jumlah penulisan jurnal terindeks scopus di antara negara Asean pada tahun 2014 menempatkan Indonesia berada di bawah Thailand. Total jumlah publikasi yang dihasilkan oleh Indonesia bahkan tidak sampai 50\% dari negara Thailand. Apabila dibandingkan dengan negara lain seperti Singapura dan Malaysia maka posisi Indonesia akan sangat tertinggal jauh.(Pardjono et al., 2017) Pada Tahun 2018 peringkatnya naik menjadi nomor 2 di Asean di bawah Malaysia.(Novialius, 2018) Berdasarkan hal tersebut penulisan karya IImiah di Indonesia perlu untuk terus ditingkatkan untuk bersaing di dunia Internasional.

STAKN Toraja (sekarang bertanformasi menjadi IAKN Toraja) perlu ikut dan ambil bagian dalam tren penulisan karya ilmiah secara Nasional sehingga dapat meningkatkan jumlah publikasi secara nasional dan secara khusus jumlah publikasi karya ilmiah di IAKN Toraja. Peningkatan publikasi karya ilmiah akan memberikan dampak yang positif bagi akreditasi Institusi. Penulisan dan penerbitan karya ilmiah merupakan pengejawantahan misi IAKN Toraja dalam melaksanakan Tridharma Perguruan Tinggi. Berdasarkan hal tersbut perlu dilakukan terbosan dalam peningkatan karya ilmiah berbasis penelitian dan publikasi di IAKNToraja.

Penyelesaian masalah tersebut salah satunya adalah dengan peningkatan publikasi ilmiah oleh para mahasiswa. Ironinya mahasiswa yang seharusnya ikut serta dalam peningkatan pembuatan karya ilmiah ini memiliki banyak tantangan dan hambatan. Hambatan yang terdapat di dalam diri mahasiswa tersebut diantaranya adalah tidak percaya diri, tidak ada mood, memilki rasa malas, kurangnya konsep pemahaman akan karya tulis ilmiah, kesulitan dalam menemukan ide, tidak ada semangat untuk memulai dan tidak tidak tertarik pada kegiatan menulis.(Rahmiati, 2014) Hal ini juga terjadi di IAKN Toraja, berkaitan dengan publikasi karya ilmiah dari mahasiswa sangat rendah. Total jumlah penelitian di IAKN Toraja tahun 2018 adalah sekitar 105 penelitian yang kebanyakan di dominasi oleh penelitian dosen meskipun ada beberapa pelibatan mahasiswa pada penelitian tersebut.(Frans Paillin Rumbi, 2019b) Rendahnya publikasi ilmiah bagi mahasiswa di IAKN Toraja juga di karenakan tidak ada wadah untuk menaungi dan meningkatkan minat penulisan mahasiswa IAKN Toraja. Berdasarkan hal tersebut dapat dibuktikan bahwa penulisan karya ilmiah mahasiswa di IAKN Toraja sangat rendah dan perlu perhatian khusus untuk peningkatan publikasi ilmiah mahasiswa di IAKN Toraja.

Masalah utama dari isu ini adalah rendahnya publikasi mahasiswa. Adapun dampak dari isu tersebut jika tidak diatasi yaitu pertama, secara global akan menurunkan daya saing Indonesia di dunia internasional berkaitan penelitian yang dilakukan secara konsekuen. Kedua, menyia-nyiakan melimpahnya sumber daya manusia yaitu mahasiswa IAKN Toraja yang memiliki potensi untuk melakukan penerbitan karya ilmiah. Ketiga, menurunkan semangat misi IAKN Toraja untuk melakukan Tri Dharma Perguruan Tinggi akibat rendahnya publikasi karya ilmiah dari mahasiswa. Keempat, merendahkan semangat bersaing Institusi IAKN Toraja di dunia nasional karena rendahnya publikasi Karya Ilmiah Mahasiswa IAKN Toraja. 
Perkumpulan Penulis IAKN Toraja merupakan suatu terobosan kegiatan untuk mengakomodasi publikasi karya ilmiah dosen dan mahasiswa. Perkumpulan Penulis merupakan suatu tempat pelatihan dan publikasi bagi para mahasiswa berdasarkan bimbingan para dosen. Rumah jurnal setiap triwulan sekali diharapkan dapat menghasilkan penelitianpenelitian dan publikasi untuk meningkatkan karya ilmiah yang ada di IAKN Toraja.

Gagasan Perkumpulan Penulis IAKN Toraja yang merupakan gagasan kreatif-inovatif ini diharapkan adanya manfaat sebagai berikut, pertama bagi institusi akan meningkatkan akreditasi di mana penelitian di kampus akan meningkat. Kedua, bagi institusi menjadikan perkumpulan ini cikal bakal Unit Kegiatan Mahasiswa dalam pelatihan softskill menulis. Ketiga, membekali mahasiswa untuk memiliki keberanian dalam berkancah di dunia penulisan nasional.

\section{METODE}

Kegiatan pengabdian kepada masyarakat ini menggunakan metode pembelajaran yang bersifat aktif, kreatif, dan inovatif atau active assessmentlearning (Munthe, 2017). Pembelajaran ini melibatkan dosen dan mahasiswa dengan hasil akhir bukan hanya memahami akan tetapi peserta dapat melakukan secara aktif tujuan dari kegiatan pengabdian yaitu penulisan jurnal penelitian. Metode ini mengajak dan melepaskan sekat antara dosen dan mahasiswa menjadi satu tim dalam satu penelitian. Metode ini secara aktif memaksa kontribusi dari peserta yaitu dosen dan mahasiswa untuk mencurahkan gagasan mereka ke dalam satu jurnal penelitian.

Teknik pelaksanaan kegiatan ini adalah dengan cara, pertama rekrutmen untuk mahasiswa dan dosen yang berkomitmen untuk bergabung dalam kegiatan ini. Kedua, melakukan pelatihan penulisan dengan pemberian motivasi, teknik-teknik penulisan, dan langkahlangkah untuk mempu-blikasikan jurnal ilmiah. Ketiga melakukan submisi atau publikasi ke dalam jurnal online/Open Jurnal System (OJS). Diharapkan tim yang teridiri atas dosen dan mahasiswa dapat membuat jurnal penelitian dan kemudian melaksanakan publikasi secara online. Publikasi online tersebut yang akan menaikan jumlah tulisan atau karya ilmiah IAKN Toraja.

\section{HASIL DAN PEMBAHASAN}

Pelaksanaan Program ini merupakan salah satu bentuk pengabdian masyarakat yaitu memberi pelatihan kepada dosen dan khususnya para mahasiswa. Kegiatan ini berlangsung selama 3 hari yaitu pada tanggal 16-18 Desember 2019 di Hotel Misiliana, Rantepao, Toraja Utara, Sulawesi Selatan.

Kegiatan ini diprakarsai oleh tiga dosen pemateri utama didukung oleh dosen-dosen yang aktif mendampingi mahasiswa dalam menulis. Tiga dosen pemateri utama tersebut yaitu Daniel Fajar Panuntun, Yohanes Krismantyo Susanta, dan Frans Paillin Rumbi.

Daniel Fajar Panuntun, memiliki profil sebagai dosen metode penelitian dengan beberapa profil karya penelitian di ranah Teologi Praktika, Teologi Kontekstual dan Apologetika. Penelitian termutakhirnya diantaranya: Fenomena media sosial pada akun satire @Gerejapalsu dan keter- 
kaitannya pada Misi Pneumatologi Holistik (Panuntun, 2020), penelitian mengenai makna Teologis dari tembang dolanan Jawa yaitu cublak-cublak suweng,(Panuntun, 2019a) dan penelitian mengenai misi di tengah era disrupsi(Panuntun, 2019b).

Yohanes Krismantyo Susanta, memilki profl sebagai dosen Sains dan Iptek dengan profil karya penelitian pada Teologi Perjanjian Lama, Biblika, dan Teologi Agama-agama. Beberapa penelitiannya diantaranya adalah: penelitian terhadap komunitas bali yang diaspora di Kabupaten konawi mengenai Sentana Rajeg dan nilai anak lakilaki(Susanta, 2019).

Frans Paillin Rumbi memiliki profil sebagai dosen Dogmatika dengan profil karya penilitian di bidang Teologi Kontekstual, Teologi Sosial, dan Dogmatika. Beberpa penelitian termuktakhirnya diantaranya adalah: mengenai politik identitas etnis Toraja di Kabupaten Kolaka(Frans Paillin Rumbi, 2019a) dan mengenai keterkaitan tradisi Masuru dan pertobatan dalam Injil Sinoptik(Frans Pailin Rumbi, 2018).

Peserta pada kegiatan ini adalah dosen dan mahasiswa yang berkomitmen meningkatkan kualitas keilmuannya. Jumlah dari peserta adalah 40 peserta dengan 11 dosen dan 29 mahasiswa. Peserta dibagi dalam kelompok-kelompok kecil untuk dapat merealisasikan dan mengembangkan idenya masing-masing.

Kegiatan ini memiliki tujuan utama untuk meningkatkan kualitas dan minat dosen dan mahasiswa dalam menulis karya Ilmiah. Indikator capaian yang dapat diperoleh dari kegiatan ini adalah para peserta memiliki minat dan memiliki naskah yang akan digarap untuk disubmit ke jurnal- jurnal online yang ada di seluruh Indonesia. Dampak yang diharapkan dalam jangka panjang adalah naskah-naskah tersebut dapat terpublikasi dalam open journal system yang ada di seluruh Indonesia. Berdasarkan hal tersebut kegiatan ini dibuat beberapa sesi untuk dapat mencapai indikator dari kegiatan ini.

Sesi pertama pada hari Senin, 16 Desember 2019 dimulai dengan pembukaan dan sambutan. Kegiatan dilanjutkan dengan penyampaian materi sebagai berikut:

\section{Pengenalan Aplikasi Reference Management Tools Mendeley dan Zotero}

Dalam kegiatan ini, pelatihan yang diberikan bertujuan untuk mempermudah sekaligus meminimalisir kesalahan yang kerap kali dilakukan oleh seorang penulis artikel ketika membuat kutipan baik berupa catatan kaki maupun daftar pustaka. Pemateri pada sesi ini adalah Daniel Fajar Panuntun dengan menggunakan metode Lokakarya sehingga para peserta dapat mengaplikasikan program mendeley dan zotero.

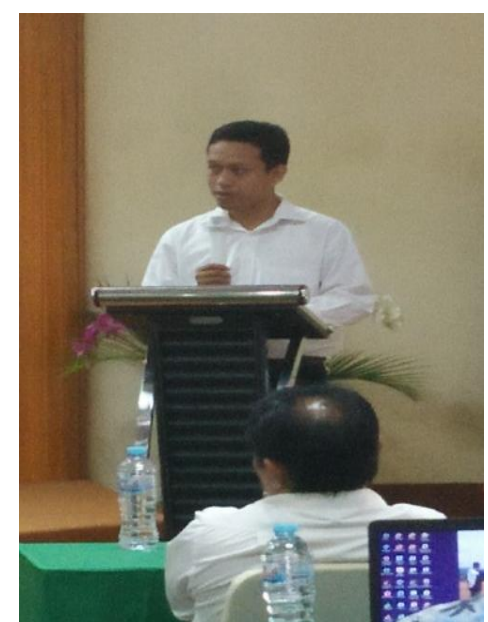

Gambar 1. Pelatihan Mendeley dan Zotero 


\section{Pelatihan Penulisan Artikel IImiah}

Kegiatan ini bertujuan untuk memberikan petunjuk penulisan dan kiat menulis sebuah artikel ilmiah, pembuatan abstrak, cara merumuskan latar belakang masalah, pernyataan tesis, dan struktur penulisan sebuah artikel jurnal ilmiah. Pelatihan penulisan Artikel ilmiah dilakukan oleh Yohanes Krismantyo Susanta. Pemaparan materi dilakukan dengan menggunakan metode kreatif inovatif ceramah drafting terpadu(Munthe, 2017, p. 151). Metode ini menekankan para audiens untuk mendengarkan ceramah dan juga membuat draft penelitian yang nantinya akan diteruskan menjadi abstrak penelitian.

\section{Pelatihan Penggunaan Open Journal System (OJS)}

Kegiatan ini bertujuan untuk memperkenalkan OJS kepada para peserta. Di dalamnya juga diberikan petunjuk dan penjelasan tentang cara melakukan registerasi hingga cara mengunggah naskah artikel ke dalam OJS.

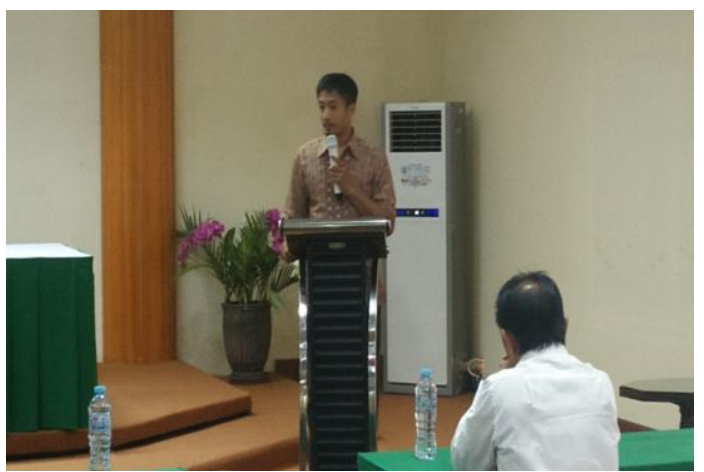

Gambar 2.Pengenalan OJS

Sesi kedua pada hari Selasa, 17 Desember 2019. Kegiatan pada hari kedua berisi penyusunan dan diskusi artikel ilmiah yang akan disusun.

\section{Diskusi Kelompok}

Dalam kegiatan ini, para peserta dibagi menjadi beberapa kelompok yang terdiri atas dosen dan para mahasiswa. Di dalam kelompok, para peserta berdialog tentang topik yang akan diangkat dan mulai menyusun abstrak artikel jurnal.

\section{Presentasi Kelompok}

Presentasi kelompok dilakukan dengan cara mengutus perwakilan yaitu satu orang dari masing-masing kelompok. Setelah melakukan presentasi, para peserta mendapatkan umpan balik atau masukkan dari para dosen yang menjadi fasilitator kegiatan ini.

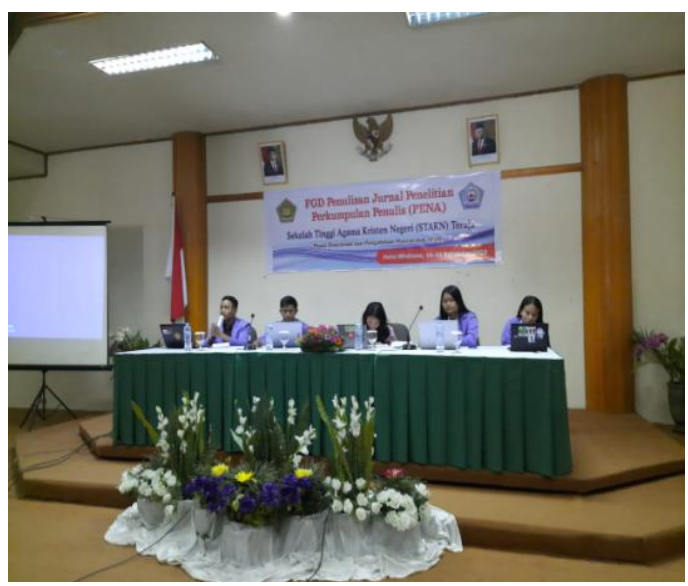

Gambar 3.Presentasi kelompok

Sesi Ketiga pada hari Rabu, 18 Desember 2019 masih merupakan kelanjutan dari sesi kedua pada hari sebelumnya. Sesi ini adalah sesi terakhir yang kemudian ditutup dengan kegiatan penutupan. 
Jurnal Widya Laksana, Vol.10, No.1, Januari 2021

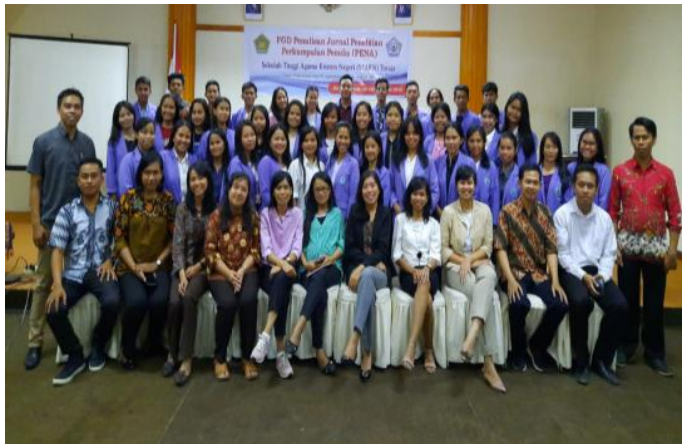

Gambar 4.Foto bersama peserta dan fasilitator kegiatan

Setelah mengikuti rangkaian kegiatan selama 3 hari, hasil dari kegiatan pengabdian ini menunjukkan bahwa para peserta mampu menyusun abstrak dan topik untuk penulisan artikel jurnal ilmiah dengan memanfaatkan panduan yang telah diberikan oleh para fasilitator.

Indikator keberhasilan dari kegiatan ini tercapai terliha dari abstrak topik penelitian yang telah terkumpul. Terdapat 19 topik asbtrak penelitian yang telah diberi masukan dan dibahasa bersama untuk kemudian dapat diteruskan menjadi tulisan ilmiah dan pada akhirnya dilakukan submisi pada beberapa open journal system di Indonesia. Dampak jangka panjang yang diharapkan juga tercapai dengan terbitnya tulisan Daniel et al di jurnal visio dei dengan judul : Model Dialog Imajiner Entas-Entas Untuk Mengko-munikasikan Kristus Kepada Masyarakat Tengger (Panuntun et al., 2020) dan naskah Febriani et al pada jurnal bia dengan judul: Pembinaan Karakter Pemuda Kristiani dalam Perspektif Nilai Longko'di Era Disrupsi (Febriani et al., 2020). Berdasarkan hal tersebut indikator capaian dari kegiatan dan harapan dari kegiatan ini dapat dikatakan berhasil.
Tantangan dari kegiatan pengabdian ini diantaranya adalah mengubah mindset mahasiswa dan dosen terhadap pentingnya karya ilmiah. Mahasiswa memahami pentingnya karya ilmiah sebagai syarat untuk skripsi dan dosen sebagai pemenuhan angka kredit. Melalui kegiatan Pena ini para peserta di berikan motivasi untuk menulis sebagai karya abadi yang nantinya ditinggalkan dan dikenang meskipun penulisanya sudah tiada. Sumbangsih pemikiran dalam bentuk tulisan ilmiah ini yang nantinya akan mendukung kepro-fesionalitasn dan kecendekiawan para mahasiswa dan dosen dalam mepertanggungjawabkan ilmi yang telah diperolehnya.

Hasil penulisan artikel ilmiah ini akan diupload atau submit ke beberapa jurnal ilmiah di Indonesia. Beberapa naskah diantaranya sudah diproses di jurnal-jurnal online hingga tahap review. Diharapkan karya-karya mahasiswa dan dosen dalam karya ilmiah IAKN Toraja terpublikasi di berbagai jurnal ilmiah. Para peserta mengaku mendapatkan banyak pengetahuan baru sekaligus termotivasi untuk menjadi penulis. Para peserta juga berharap kegiatan PENA ini dapat tetap dilanjutkan untuk menghasilkan tulisan dan mencetak para penulis jurnal muda yang potensial di masa mendatang.

\section{KESIMPULAN}

Kegiatan pengabdian Perkumpuan Penulis IAKN Toraja merupakan kegiatan yang sangat bermanfaat dengan tujuan utama meningkatkan publikasi karya ilmiah IAKN Toraja. Pengabdian ini menghasilkan abstrak artikel-artikel penelitian yang siap untuk diteruskan menjadi artikel ilmiah. Beberapa diantaranya sudah melakukan submit di open jurnal system. Pengabdian 
Jurnal Widya Laksana, Vol.10, No.1, Januari 2021

ini sangat bermanfaat dalam meningkatkan kemapuan kritis mahasiswa dan perubahan mindset dosen dalam menulis karya ilmiah.

\section{DAFTAR PUSTAKA}

Febriani, F., Sari, D. R., \& Bua, A. N. T. (2020). Pembinaan Karakter Pemuda Kristiani dalam Perspektif Nilai Longko'di Era Disrupsi. BIA': Jurnal Teologi Dan Pendidikan Kristen Kontekstual, 3(1).

Munthe, B. (2017). StrategiMengajar Aktif Kreatif Inovatif. Uka Press.

Novialius, F. (2018). Publikasi IImiah Indonesia Peringkat 2 ASEAN. Okenews. https://news.okezone.com/read/2018/1 0/24/65/1968471/publikasi-ilmiahindonesia-peringkat-2-di-asean

Panuntun, D. F. (2019a). Makna Nilai-nilai Kristen Lagu Cublak-cublak Suweng. Forte, 1(1).

Panuntun, D. F. (2019b). Misi Apologetika Kristen Online di Era Diruspsi. Apostolos, 2(1).

Panuntun, D. F. (2020). The Social Media Phenomenon Of Satire Account @Gerejapalsu In The Movement Of Holistic Pneumatology In Mission. Jurnal Gamaliel: Teologi Praktika, 2(1).

Panuntun, D. F., Pute, J. P., \& Mangalik, L. A. (2020). Model Dialog Imajiner
Entas-Entas

Untuk

Mengkomunikasikan Kristus Kepada

Masyarakat Tengger. Visio Dei: Jurnal Teologi Kristen, 2(1), 84-104. https://doi.org/10.35909/visiodei.v2i1.6 2

Pardjono, Nuchron, Surono, \& Ramdani4, S. D. (2017). Analisis Faktor-Faktor Penghambat Produktivitas Publikasi Karya Ilmiah Mahasiswa PPs UNY pada Jurnal Internasional Terindeks. 2(2), 139-147.

Rahmiati. (2014). Analisis Kendala Internal Mahasiswa Dalam Menulis Karya IImiah. Al-Daulah, 3(2), 327-343.

Rumbi, Frans Pailin. (2018). Tradisi Massuru'dan Pertobatan Dalam Injil Sinoptik. BIA': Jurnal Teologi Dan Pendidikan Kristen Kontekstual, 1(1), 26-38.

Rumbi, Frans Paillin. (2019a). Politik Identitas Etnis Toraja sebagai Masalah Teologis: Kasus di Kabupaten Kolaka, Sulawesi Tenggara. KURIOS (Jurnal Teologi Dan Pendidikan Agama Kristen), 5(2), 125-138.

Rumbi, Frans Paillin. (2019b). Wawancara Mengenai Penulisan di STAKN Toraja.

Susanta, Y. K. (2019). Sentana Rajeg Dan Nilai Anak Laki-Laki Bagi Komunitas Bali Diaspora Di Kabupaten Konawe. Harmoni, 18(1), 504-518. 